\title{
Positieve Gezondheid en gezondheidspercepties van mensen met een lage SES
}

\section{Resultaten van negen concept-mappingsessies in vijf regio's}

\author{
Francisca Flinterman · Pascal Bisscheroux · Paula Dijkema · Frank den Hertog · Marja de Jong · Anita Vermeer • \\ Manon Vosjan
}

Published online: 23 April 2019

(C) The Author(s) 2019

Samenvatting Het concept Positieve Gezondheid met haar zes dimensies, zoals door Machteld Huber en anderen ontwikkeld, wordt in toenemende mate gebruikt in de wereld van gezondheid en zorg. Ook GGD'en willen dit concept graag inzetten binnen de context van hun gezondheidsbevorderingspraktijk. Het concept moet dan wel aansluiten bij de gezondheidspercepties van mensen met een lage sociaaleconomische status (SES), een belangrijke doelgroep voor gezondheidsbevordering door GGD'en. Dit artikel beschrijft een onderzoek naar de manier waarop mensen met een lage SES het begrip gezondheid operationaliseren, wat zij belangrijk vinden en in hoeverre

Dr. F. Flinterman $(\bowtie)$

Afdeling Epidemiologie Gezondheidsbevordering en Zorginnovatie, GGD Amsterdam, Amsterdam, Nederland fflinterman@ggd.amsterdam.nl

\section{P. Bisscheroux}

Cluster Maatschappelijke Ontwikkeling, Directie Publieke Gezondheid Welzijn en Zorg, gemeente Rotterdam,

Rotterdam, Nederland

\section{Ir. P. Dijkema}

Sector Gezondheidsbevordering, GGD Brabant-Zuidoost, Eindhoven, Nederland

\section{Dr. F. den Hertog}

Afdeling Kennisintegratie Volksgezondheid en Zorg, Centrum Gezondheid en Maatschappij, Rijksinstituut voor Volksgezondheid en Milieu, Bilthoven, Nederland

\section{Ir. M. de Jong $\cdot$ M. Vosjan}

Kennis en Expertisecentrum, GGD IJsselland, Zwolle, Nederland

\section{Dr. A. Vermeer}

Afdeling Kennis \& Innovatie, GGD Zuid Limburg, Geleen, Nederland hun perceptie aansluit bij het spinnenwebmodel van Positieve Gezondheid. Hiertoe zijn negen conceptmappingbijeenkomsten georganiseerd in vijf verschillende gemeenten, verspreid over Nederland. Uit de resultaten blijkt dat mensen met een lage SES een brede blik op gezondheid hebben, die grotendeels overeenkomt met de zes dimensies van Positieve Gezondheid. Alleen op het niveau van gezondheidsaspecten wijkt hun perceptie in een aantal gevallen af van het spinnenwebmodel. Voor een betere aansluiting van het model bij de belevingswereld van mensen met een lage SES, adviseren wij enkele aanpassingen. Daarnaast is het belangrijk om een plek te geven aan determinanten van gezondheid, omdat mensen met een lage SES deze ook als onderdelen van gezondheid zien.

Trefwoorden Positieve Gezondheid · lage SES • concept-mapping · gezondheidspercepties

\section{Kernpunten}

- Mensen met een lage SES hebben een brede kijk op gezondheid, waarin de zes dimensies van Positieve Gezondheid te herkennen zijn.

- Op aspectniveau en vooral in terminologie wijkt de perceptie van mensen met een lage SES af van het bestaande model.

- Mensen met een lage SES maken geen onderscheid tussen indicatoren en determinanten.

- Voor succesvol gebruik van het model van Positieve Gezondheid voor mensen met een lage SES zijn enkele wijzigingen en toevoegingen aan te bevelen. 
- Basis Algemene Dagelijkse Levensverrichtingen (ADL)

- Instrumentele ADL

- Werkvermogen

- Gezondheidsvaardigheden

- Sociale en communicatieve vaardigheden

- Sociale contacten

- Betekenisvolle relaties

- Geaccepteerd worden

- Maatschappelijke betrokkenheid

- Betekenisvol werk

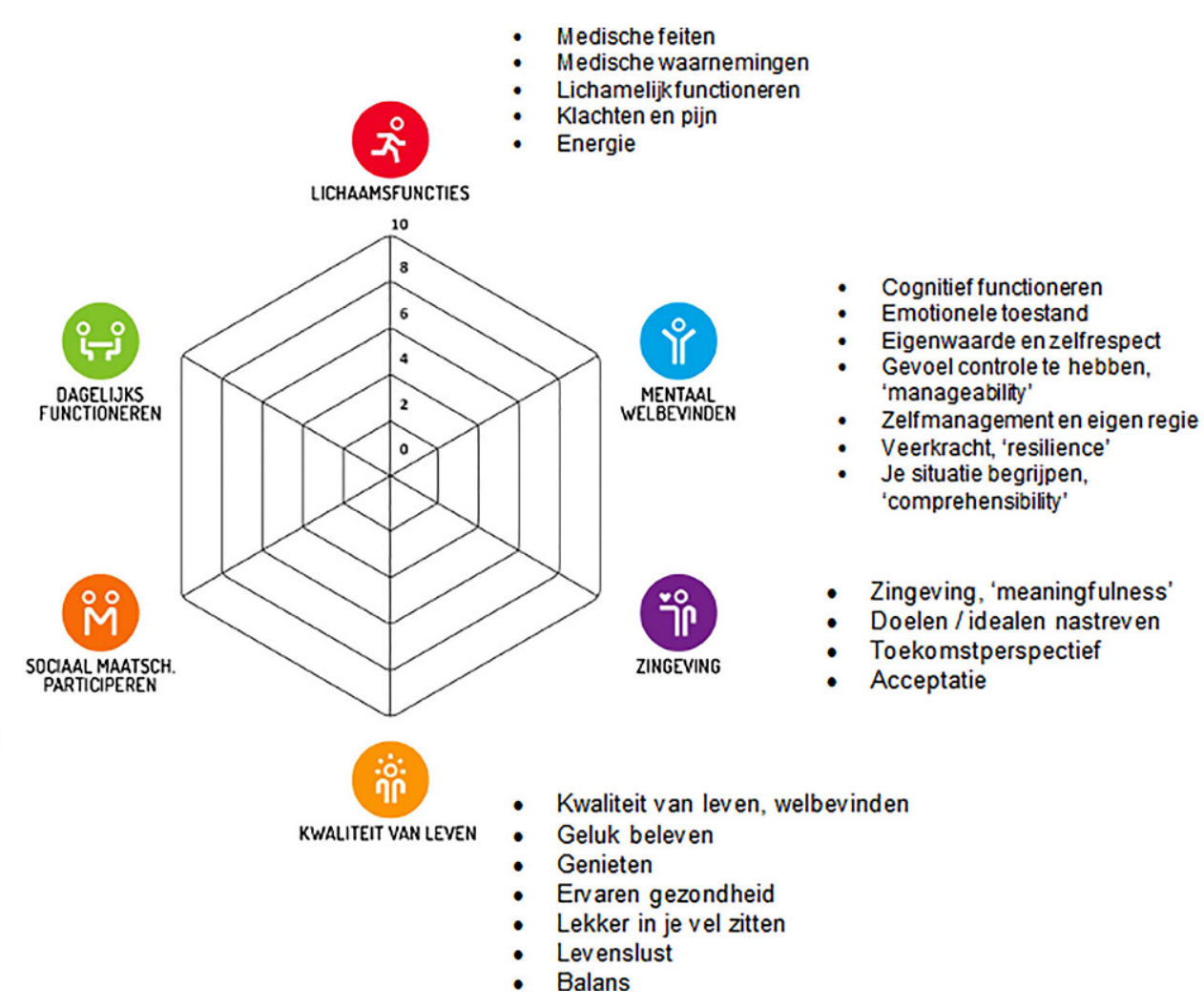

- Medische feiten

- Klachten en pijn

ICHAAMSFUNCIIES

Emotionele

Eigenwaarde enzelfrespect Gevoel controle te hebben,

Veerkracht 'resilience'

Je situatie begrijpen, 'comprehensibility'

Zingeving, 'meaningfulness'

Doelen / idealen nastreven

Toekomstperspectief

Acceptatie

Figuur 1 Het spinnenweb van Positieve Gezondheid, gebaseerd op de resultaten van het onderzoek als beschreven in Huber et al. [2, 3]

\section{Positive Health and health perceptions of people with lower SES}

The results of nine concept mapping sessions in five locations

Abstract The new concept of Positive Health, as launched by Machteld Huber and others, is widely deployed by public health and health care organizations in the Netherlands, both in policy and in practice. For public health services, an important condition for embracing this concept in collective prevention is its consistency with health perceptions of people with a low socioeconomic status (SES). Since socioeconomic disadvantages are associated with poorer health, low-SES people form important target groups of public health services. This article describes the exploration of health perceptions of low-SES people by means of nine concept mapping meetings in five different locations. Results show that low-SES people hold a broad idea of health compatible to the six dimensions of Positive Health. With some essential adaptations at the level of aspects the model of Positive Health is quite suitable for health discussions with low-SES people. Since people don't distinguish health indicators from health determinants, it is recommended that health determinants should be part of an overarching model as well.

Keywords Positive Health · Low-SES · concept mapping $\cdot$ health perceptions

\section{Inleiding}

In 2011 lanceerde Machteld Huber met een internationaal team van gezondheidsexperts een nieuw concept van gezondheid: gezondheid als het 'vermogen om je aan te passen en je eigen regie te voeren in het licht van de fysieke, emotionele en sociale uitdagingen van het leven' [1]. In een vervolgonderzoek onder allerlei stakeholders is dit concept geoperationaliseerd tot het concept Positieve Gezondheid, bestaande uit 33 indicatoren of aspecten van gezondheid, onderverdeeld in zes dimensies $[2,3]$. Positieve Gezondheid wordt in de praktijk veelal gevisualiseerd als een spinnenweb (fig. 1).

Inmiddels wordt het concept Positieve Gezondheid in Nederland omarmd door veel professionals uit de gezondheidszorg, de publieke gezondheid en het sociaal domein. Het stimuleert cliëntgericht en integraal werken en legt de nadruk op veerkracht en eigen regie. Ook veel GGD'en willen hun beleid en praktijk laten aansluiten bij dit nieuwe, bredere concept van gezondheid.

Voorwaarde voor gebruik van het concept binnen de publieke gezondheid is dat het aansluit bij, en toepasbaar is voor, mensen met een lage SES (sociaaleconomische status, de positie van mensen op de maatschappelijke ladder, bepaald door opleiding, inkomen en de positie op de arbeidsmarkt) [4]. Mensen met een lage SES vormen een belangrijke aandachtsgroep voor 
Tabel 1 Samenstelling van de deelnemers van de concept-mappingbijeenkomsten

\begin{tabular}{|c|c|c|c|c|c|c|c|c|c|}
\hline Plaats (datum) & $\begin{array}{l}\text { Utrecht } 1 \\
\text { (17.04.15) }\end{array}$ & $\begin{array}{l}\text { Utrecht } 2 \\
(09.07 .15)\end{array}$ & $\begin{array}{l}\text { Amsterdam } 1 \\
\text { (19.02.16) }\end{array}$ & $\begin{array}{l}\text { Amsterdam } 2 \\
(28.04 .16)\end{array}$ & $\begin{array}{l}\text { Eindhoven } \\
\text { (17.05.16) }\end{array}$ & $\begin{array}{l}\text { Rotterdam } 1 \\
\text { (24.05.16) }\end{array}$ & $\begin{array}{l}\text { Rotterdam } 2 \\
(26.05 .16)\end{array}$ & $\begin{array}{l}\text { Rotterdam } 3 \\
(26.09 .16)\end{array}$ & $\begin{array}{l}\text { Vollenhove } \\
\text { (09.11.16) }\end{array}$ \\
\hline Aantal & 13 & 17 & 13 & 8 & 18 & 17 & 17 & 15 & 15 \\
\hline Etniciteit & NL & NW (Marokko) & NL & $4 \mathrm{NL}, 4 \mathrm{NW}$ & NW (Turkije) & $\begin{array}{l}9 \mathrm{NL}, 7 \mathrm{NL}^{*}, \\
1 \mathrm{~W}\end{array}$ & $\begin{array}{l}12 \mathrm{Nl}, 4 \mathrm{NL}^{*}, \\
1 \mathrm{NW}\end{array}$ & $\mathrm{NL}^{*}$ & $14 \mathrm{NL}, 1 \mathrm{~W}$ \\
\hline $\begin{array}{l}\text { Leeftijdsspreiding } \\
\text { (gemiddelde) }\end{array}$ & $45-85(68)$ & $19-58(44)$ & $63-90(76)$ & $42-82(62)$ & $34-58(47)$ & $18-63(35)$ & $21-74$ (53) & $18-48$ (29) & $24-62(42)$ \\
\hline Geslacht & $2 m, 11 v$ & $17 v$ & $3 \mathrm{~m}, 10 \mathrm{v}$ & $3 m, 5 v$ & $18 \mathrm{v}$ & $5 \mathrm{~m}, 12 \mathrm{v}$ & $3 m, 14 v$ & $1 \mathrm{~m}, 14 \mathrm{v}$ & $5 \mathrm{~m}, 10 \mathrm{v}$ \\
\hline $\begin{array}{l}\text { Overige } \\
\text { kenmerken }\end{array}$ & & & niet werkend & $\begin{array}{l}2 \text { vluchtelin- } \\
\text { gen }\end{array}$ & & werkloos & $\begin{array}{l}10 \text { chronisch } \\
\text { ziek }\end{array}$ & & $\begin{array}{l}8 \text { werkend, } \\
7 \text { werkloos }\end{array}$ \\
\hline
\end{tabular}

de publieke gezondheid omdat zij meer risico lopen op gezondheidsproblemen [5-11].

Er is echter nog weinig onderzoek gedaan naar de gezondheidspercepties van mensen met een lage SES [12-16] en dus ook weinig zicht op de vraag of het concept Positieve Gezondheid daarbij aansluit. Een landelijke GGD-werkgroep Positieve Gezondheid en lage SES heeft zich over deze vraag gebogen en systematisch onderzocht welke invulling mensen met een lage SES aan het begrip gezondheid geven en in hoeverre deze overeenkomt met het concept Positieve Gezondheid met de zes dimensies.

\section{Concept-mapping}

De percepties van gezondheid van mensen met een lage SES zijn in kaart gebracht aan de hand van concept-mapping [17]. In 2015 en 2016 zijn in vier steden, Utrecht, Amsterdam, Eindhoven en Rotterdam, en in het dorp Vollenhove (gemeente Steenwijkerland), negen bijeenkomsten georganiseerd waaraan in totaal 133 inwoners met lage SES deelnamen. De bijeenkomsten vonden steeds plaats op een gemakkelijk toegankelijke en vertrouwde locatie in de buurt.

De deelnemers zijn op verschillende wijzen geworven. In Utrecht is dat gedaan via flyers, huisartsenposten, buurtwerkers en het aanspreken van mensen bij een supermarkt, in Amsterdam door middel van flyers en persoonlijke uitnodigingen door wijkzorg en een woningcorporatie, en in Rotterdam is gebruikgemaakt van het bestaande panel van een onderzoeksbureau en een Facebook-advertentie. In deze drie steden is geselecteerd op een laag opleidingsniveau (ten hoogste vmbo, mavo of mbo-1) [18]. Bij de eerste bijeenkomst in Rotterdam was werkzoekend zijn een aanvullend criterium. In Eindhoven is aangesloten bij een vereniging van allochtone (in het bijzonder Turkse) vrouwen en in Vollenhove is geworven onder bezoekers van een voedselbank, waarmee op een laag inkomen is geselecteerd. Om de werving te ondersteunen, hebben de deelnemers van sommige bijeenkomsten een bescheiden beloning gekregen. Mede vanwege de uiteenlopende wervings- en selectiemethoden varieerde de samenstelling van de groepen deelnemers sterk in leeftijd, etnische herkomst en participatiegraad. Verreweg het grootste deel van de deelne- mers $(83 \%)$ was vrouw. In tab. 1 is de samenstelling van de verschillende groepen weergegeven.

In alle groepen is dezelfde concept-mappingmethode gebruikt [19], waarin de deelnemers achtereenvolgens de volgende vragen voorgelegd kregen:

1. Wat is gezondheid voor $\mathrm{u}$ ?

Deelnemers werd plenair gevraagd zo veel mogelijk aspecten van gezondheid te noemen door de zin af te maken 'Gezondheid is voor mij ...'. Alle aspecten werden verzameld op een cumulatieve, voor iedereen zichtbare lijst. Deze aspecten werden vervolgens geprint op kaartjes waarvan iedere deelnemers twee sets kreeg.

2. Welke onderdelen van gezondheid horen volgens $u$ bij elkaar?

Elke deelnemer werd gevraagd om individueel de verzamelde aspecten, weergegeven op losse kaartjes, te clusteren en de ontstane clusters een passende, inhoudelijke naam te geven.

3. Welke onderdelen van gezondheid vindt $\mathrm{u}$ het belangrijkst?

Elke deelnemer kreeg de individuele opdracht alle aspecten, weergegeven op een tweede set kaartjes, te sorteren naar mate van belangrijkheid, van $1=$ minst belangrijk tot $5=$ meest belangrijk, waarbij de kaartjes maximaal gespreid moest worden over de vijf niveaus van waardering.

\section{Gezondheid volgens lage SES}

In elke groep zijn tussen de 45 en 80 aspecten van gezondheid verzameld die steeds een vergelijkbare breedte omvatten. Zo werden in alle groepen aspecten als 'niet ziek zijn', 'voldoende bewegen', 'lachen' maar ook 'groen in de buurt' en 'goede vrienden hebben' genoemd.

Het clusteren van de statements vonden veel deelnemers lastig. Zelfs met hulp (door de vraag te stellen 'hoort dit kaartje meer bij dit of bij dat stapeltje?') was de opdracht voor sommigen heel moeilijk. Er ontstonden clusters zonder naam, clusters met nietinhoudelijke namen (zoals 'niet belangrijk' of 'ben ik nog niet aan toe') of clusters met namen die maar een beperkt deel van de inhoud omvatten (zoals 'Dennis mijn huisarts' voor een cluster met ook niet-zorggerelateerde kenmerken). 
Tabel 2 Vergelijking van de door mensen met een lage SES genoemde aspecten van gezondheid met de indicatoren van Positieve Gezondheid volgens Huber (in cursief zijn verschillen aangegeven)

\begin{tabular}{|c|c|c|c|c|}
\hline Dimensie & Indicatoren & Aspecten van gezondheid lage SES & Frequentie $^{\mathrm{a}}$ & Prioriteit $^{b}$ \\
\hline Positieve Gezondheid Huber & \multicolumn{4}{|l|}{ Positieve Gezondheid Huber } \\
\hline \multirow[t]{7}{*}{ Lichaamsfuncties } & medische feiten/waarnemingen & $\begin{array}{l}\text { geen ziekte hebben, niet ziek zijn, ziekte onder controle } \\
\text { hebben, niet afhankelijk zijn van medische zorg }\end{array}$ & 6 & $1,6-4,2$ \\
\hline & & gezond gewicht, slank zijn & 5 & $1,9-3,6$ \\
\hline & lichamelijk functioneren & $\begin{array}{l}\text { goed kunnen zien, ademen, bewegen, geen beperkin- } \\
\text { gen }\end{array}$ & 9 & $2,7-4,6$ \\
\hline & klachten en pijn & $\begin{array}{l}\text { vrij zijn van klachten, leven zonder pijn, je lichamelijk } \\
\text { goed voelen }\end{array}$ & 7 & $1,9-4,2$ \\
\hline & energie & fit zijn, goede conditie hebben & 7 & $2,5-4,7$ \\
\hline & & goed slapen & 6 & $1,6-4,7$ \\
\hline & & $\begin{array}{l}\text { kunnen voorkomen van ziek worden, goed immuunsys- } \\
\text { teem }\end{array}$ & 2 & $3,1-4,8$ \\
\hline \multirow{10}{*}{$\begin{array}{l}\text { Mentale functies en } \\
\text { beleving }\end{array}$} & cognitief functioneren & goed kunnen denken, concentreren, bij de tijd zijn & 7 & $1,8-4,7$ \\
\hline & emotionele toestand & geestelijk goed voelen, rustig voelen, niet piekeren & 4 & $2,7-3,8$ \\
\hline & eigenwaarde en zelfrespect & gelukkig/tevreden zijn met jezelf, jezelf kunnen zijn & 6 & $1,8-4,2$ \\
\hline & gevoel controle te hebben, manageability & & & \\
\hline & & $\begin{array}{l}\text { geen zorgen of stress hebben, kunst om dingen los te } \\
\text { laten, gezonde spanning }\end{array}$ & 7 & $2,2-4,1$ \\
\hline & zelfmanagement en eigen regie & $\begin{array}{l}\text { zelfstandig, onafhankelijk zijn, zelf problemen oplossen, } \\
\text { leven op de rit hebben }\end{array}$ & 6 & $1,8-3,9$ \\
\hline & veerkracht, resilience & $\begin{array}{l}\text { leren leven met pijn, niet bij de pakken neerzitten, } \\
\text { omgaan met je rugzakje, innerlijke kracht }\end{array}$ & 7 & $2,3-3,4$ \\
\hline & & positief zijn, het goede in mensen zien & 7 & $2,8-3,8$ \\
\hline & je situatie begrijpen, comprehensibility & - & & \\
\hline & & geen psychische aandoening of verslaving hebben & 5 & $2,5-4,1$ \\
\hline \multirow[t]{5}{*}{$\begin{array}{l}\text { Spirituele/existentiële } \\
\text { dimensie (zingeving) }\end{array}$} & zingeving, meaningfulness & $\begin{array}{l}\text { een geloof hebben/praktiseren, energie uit je geloof } \\
\text { halen }\end{array}$ & 5 & $0,7-4,1$ \\
\hline & doelen of idealen nastreven & & & \\
\hline & & dat het goed gaat met de kinderen & 3 & $2,9-4,7$ \\
\hline & toekomstperspectief & goed plannen van de toekomst, groeien in je werk & 2 & $1,5-3,3$ \\
\hline & acceptatie & $\begin{array}{l}\text { tevreden zijn, accepteren van de situatie, waarderen wat } \\
\text { je hebt }\end{array}$ & 4 & $2,9-3,5$ \\
\hline \multirow[t]{11}{*}{ Kwaliteit van Leven } & kwaliteit van leven, welbevinden & - & & \\
\hline & geluk beleven & gelukkig zijn, gelukkig voelen, geluk hebben in je leven & 7 & $1,5-4,2$ \\
\hline & genieten & $\begin{array}{l}\text { plezier hebben, lachen, genieten, voldaan gevoel nastre- } \\
\text { ven, leuke dingen kunnen doen, lol in je werk hebben }\end{array}$ & 8 & $2,4-4,3$ \\
\hline & ervaren gezondheid & - & & \\
\hline & lekker in je vel zitten & lekker in je vel zitten & 5 & $3,3-4,3$ \\
\hline & levenslust & zin hebben in de dag, je 's ochtends blij voelen & 3 & $2,9-4,1$ \\
\hline & balans & $\begin{array}{l}\text { geestelijk en lichamelijk in balans zijn, rust en structuur, } \\
\text { harmonie in dagelijks leven, stabiliteit }\end{array}$ & 6 & $2,9-3,8$ \\
\hline & & in vrijheid leven, je vrij voelen & 4 & $2,9-3,9$ \\
\hline & & prettig wonen, het thuis fijn hebben, je veilig voelen & 5 & $2,9-4,5$ \\
\hline & & voldoende geld hebben, geen schulden hebben & 6 & $1,7-4,5$ \\
\hline & & (goede) seks en liefde & 3 & $2,3-4,4$ \\
\hline
\end{tabular}

Ook het prioriteren was voor een aantal deelnemers niet gemakkelijk. Zij noemden veel aspecten heel belangrijk en vonden het ingewikkeld om onderscheid te maken in mate van belangrijkheid. Daarnaast bleek dat enkele deelnemers de mate van belangrijkheid koppelden aan wat voor hen op dat moment van toepassing was. Zo werd 'niet ziek zijn' door een vrouw als minst belangrijk geprioriteerd omdat het voor haar op dat moment niet speelde. Zij was immers niet ziek.

Hoewel de breedte aan verzamelde aspecten in de verschillende groepen grotendeels overeenkwam, varieerden de prioriteiten per groep sterk. Dit kan verklaard worden door de verschillen in karakteristieken van de groepen. Enkele voorbeelden: 


\begin{tabular}{|c|c|c|c|c|}
\hline Dimensie & Indicatoren & Aspecten van gezondheid lage SES & Frequentie $^{\mathrm{a}}$ & Prioriteit $^{b}$ \\
\hline Positieve Gezondheid Huber & Positieve Gezondheid Huber & & & \\
\hline \multirow{7}{*}{$\begin{array}{l}\text { Sociaal-maatschappelijk } \\
\text { participeren }\end{array}$} & sociale en communicatieve vaardigheden & goed Nederlands kunnen & 1 & 3,3 \\
\hline & sociale contacten & $\begin{array}{l}\text { sociale contacten, sociale controle, gezelligheid, samen } \\
\text { dingen doen of delen, huisdieren }\end{array}$ & 9 & $1,5-4,3$ \\
\hline & betekenisvolle relaties & $\begin{array}{l}\text { goede vrienden hebben, iemand om mee te praten, } \\
\text { verbonden zijn met andere mensen, liefde geven en } \\
\text { ontvangen }\end{array}$ & 7 & $2,2-4,3$ \\
\hline & geaccepteerd worden & $\begin{array}{l}\text { complimentjes krijgen, niet gediscrimineerd of gemani- } \\
\text { puleerd worden }\end{array}$ & 2 & $2,2-3,1$ \\
\hline & maatschappelijke betrokkenheid & $\begin{array}{l}\text { goed zijn voor het milieu, meedoen in de maatschappij, } \\
\text { actief blijven in de samenleving }\end{array}$ & 3 & $2,1-3,4$ \\
\hline & betekenisvol werk & $\begin{array}{l}\text { (leuk) werk hebben, bijdragen aan de maatschappij, } \\
\text { eigen bedrijfje }\end{array}$ & 5 & $0,9-3,4$ \\
\hline & & $\begin{array}{l}\text { goede band met gezin en familie, een stabiele thuissitua- } \\
\text { tie, met familie op stap gaan }\end{array}$ & 8 & $1,9-4,6$ \\
\hline \multirow[t]{4}{*}{ Dagelijks functioneren } & $\begin{array}{l}\text { basis algemene dagelijkse levensverrich- } \\
\text { tingen (ADL) }\end{array}$ & $\begin{array}{l}\text { zonder hulpmiddelen kunnen wandelen, zelfstandig } \\
\text { lichamelijk functioneren }\end{array}$ & 2 & $2,2-4,7$ \\
\hline & instrumentele ADL & $\begin{array}{l}\text { kleine dingen in huishouden kunnen doen, alles zelf } \\
\text { doen zonder hulp, lang in eigen huis wonen }\end{array}$ & 3 & $1,7-4,6$ \\
\hline & werkvermogen & kunnen werken & 3 & $2,9-3,7$ \\
\hline & gezondheidsvaardigheden & $\begin{array}{l}\text { op tijd naar de dokter gaan, medicijnen gebruiken, } \\
\text { bewust met je gezondheid omgaan, naar mijn lichaam } \\
\text { luisteren, openstaan voor hulp van anderen }\end{array}$ & 5 & $2,5-3,9$ \\
\hline
\end{tabular}

- In de groepen met niet-westerse vrouwen (Utrecht 2 en Eindhoven) had een stabiel en harmonieus gezinsleven verreweg de hoogste prioriteit.

- In een groep met vooral chronisch zieken (Rotterdam 2) waren 'kunnen functioneren' en 'goede medische hulp' de twee meest belangrijke aspecten.

- In een groep met voornamelijk 65-plussers (Amsterdam 1) bleken lichamelijke gezondheid en zelfstandig kunnen functioneren het belangrijkst.

- Bij de voedselbankklanten in Vollenhove werd 'het thuis fijn hebben' het hoogst geprioriteerd (en niet het hebben van financiële ruimte).

De prioriteiten binnen de verschillende groepen liepen dermate uiteen dat het zinloos is om een uitspraak te doen over gemiddelde prioriteiten van mensen met een lage SES. Daarbij komt dat de samenstelling van de lijst met aspecten per groep iets verschilde.

\section{Vergelijking met Positieve Gezondheid}

Om de vergelijking van het lage SES-perspectief op gezondheid met het concept Positieve Gezondheid te kunnen maken, zijn alle genoemde aspecten van gezondheid verzameld in één bestand, waarbij verdubbelingen zijn weggelaten. Vervolgens hebben vier auteurs (FF, FdH, MdJ, MV) de aspecten eerst individueel en daarna gezamenlijk vergeleken met, en gekoppeld aan, de indicatoren en dimensies van het Positieve Gezondheid-model van Huber (fig. 1). Via discussie is daarbij tot consensus gekomen. De clustering van de deelnemers zelf is losgelaten vanwege de zeer grote onderlinge verschillen, waardoor ze niet te middelen waren. Wel is de clustering waar nodig gebruikt om de interpretatie van aspecten te checken.

In tab. 2 is deze koppeling van lage SES-aspecten aan de indicatoren van Positieve Gezondheid weergegeven, waarbij steeds is vastgehouden aan de formuleringen van de deelnemers. Uit deze tabel blijkt dat veel van de door mensen met een lage SES genoemde indicatoren van gezondheid overeenkomen met indicatoren van Positieve Gezondheid. Enkele verschillen zijn:

- Binnen de dimensie Lichaamsfuncties zijn medische feiten en waarnemingen niet als zodanig door mensen met een lage SES genoemd. Men noemde 'geen ziekte hebben', 'mijn ziekte onder controle hebben' of 'niet afhankelijk zijn van medicatie'. Omdat daarbij onderscheid gemaakt wordt tussen medische feiten en waarnemingen, hebben we die twee aspecten van Positieve Gezondheid samengevoegd. In vijf van de negen groepen is bovendien 'gezond gewicht' genoemd, wat beschouwd kan worden als medische waarneming.

Een aspect dat in twee van de negen groepen is genoemd maar niet in het model van Huber voorkomt, is 'goed immuunsysteem', ofwel een goede weerstand. Deze toevoeging is opvallend omdat ze beschouwd kan worden als de lichamelijke tegenhanger van veerkracht, een aspect dat onder de dimensie Mentaal welbevinden valt. 
Zelfstandig kunnen functioneren Alles in huis doen zonder hulp Kunnen werken

Weten wat goed is voor je gezondheid
Goed Nederlands kunnen Sociale contacten hebben Goede vrienden hebben - Geaccepteerd worden

Meedoen in de maatschappij

- Werk hebben

- Goede band met gezin en familie hebben

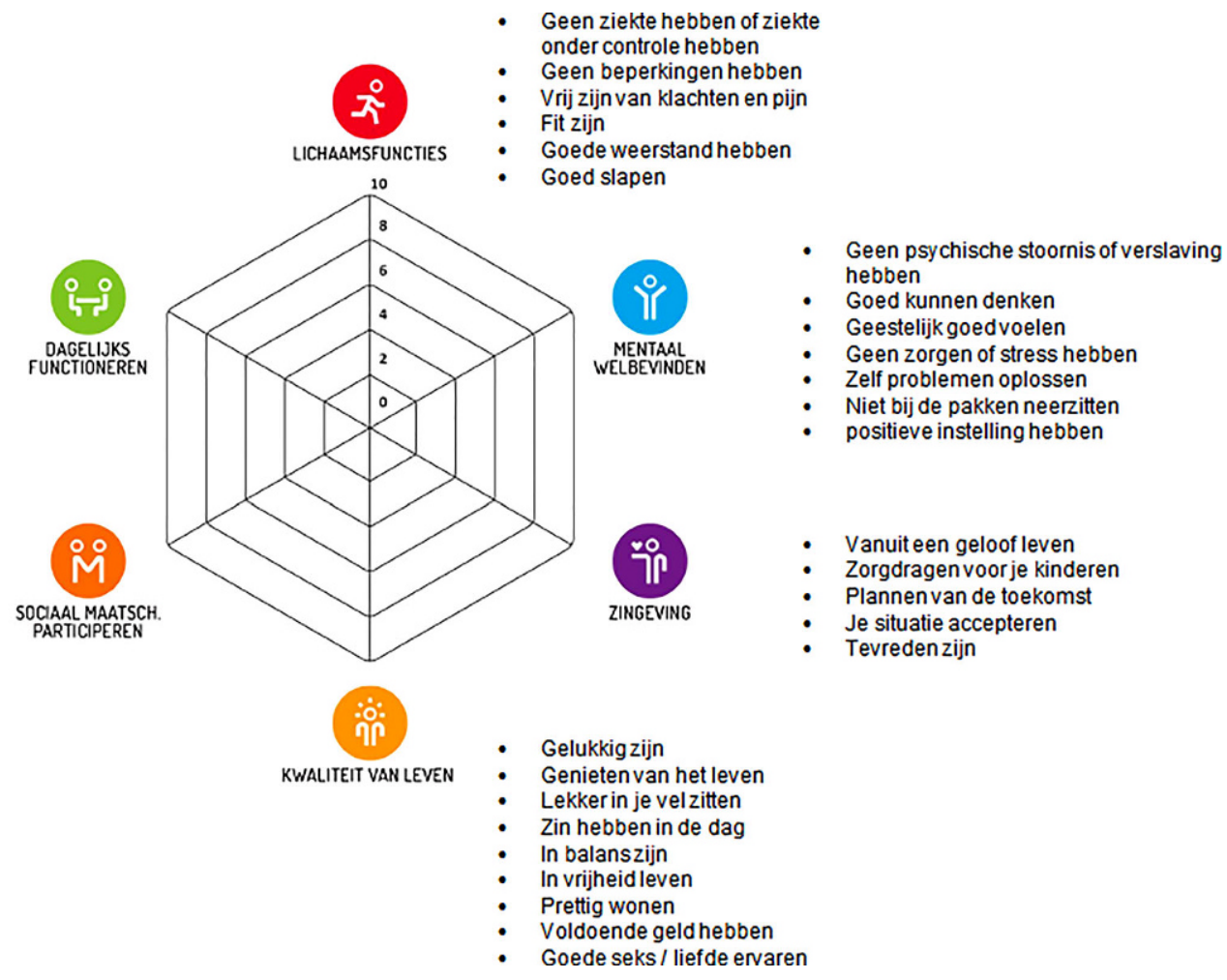

Figuur 2 Het spinnenweb van Positieve Gezondheid op basis van de resultaten van de concept-mapping met mensen met een lage SES

Daarnaast is 'goed slapen' in zes van de negen groepen naar voren gebracht. Omdat dit kenmerk in de bijeenkomsten veelal gekoppeld is aan energiek en uitgeslapen wakker worden, is het bij de dimensie Lichaamsfuncties geplaatst.

- Binnen de dimensie Mentaal welbevinden was een in vijf groepen genoemd extra aspect 'geen psychische aandoening of verslaving hebben', de medische component van deze dimensie.

'Veerkracht', 'gevoel controle te hebben' en 'je situatie begrijpen' zijn niet als zodanig door deelnemers genoemd. In plaats van het woord 'veerkracht' gaven mensen beschrijvingen als 'niet bij de pakken neerzitten' en 'omgaan met je rugzakje'. Ook 'positief zijn', in zes van de negen groepen genoemd, heeft met veerkracht te maken. In zeven groepen werd 'geen zorgen of stress hebben' naar voren gebracht, wat verband houdt met 'gevoel controle te hebben' van Huber.

- Binnen de dimensie Zingeving is het nastreven van doelen of idealen niet of nauwelijks genoemd. Wel is in drie groepen het aspect 'dat het goed gaat met de kinderen' ter sprake gekomen. Hoewel er ook argumenten zijn om dit aspect te plaatsen onder Mentaal welbevinden, als onderdeel van 'geen zorgen of stress hebben', is ervoor gekozen het onder Zingeving te plaatsen, omdat dit aspect voor meerdere deelnemers een heel essentieel levensdoel of ideaal vertegenwoordigde.
- Bij Kwaliteit van Leven zijn als extra aspecten ten opzichte van het model van Huber 'leven in vrijheid', 'je veilig voelen', 'prettig wonen' en 'voldoende geld hebben' genoemd. Omdat kwaliteit van leven een subjectieve notie is, hebben we ons beperkt tot die aspecten die verwijzen naar ervaringen. Aspecten die verwijzen naar feitelijke woon- of financiële situaties zijn opgenomen in een extra dimensie Leefomgeving (zie onder het kopje Determinanten). Ook 'seks en liefde' is als extra aspect in drie van de negen groepen genoemd. Hoewel er ook argumenten zijn om dit aspect onder Lichamelijk functioneren of Sociale participatie te plaatsen, is hier gekozen voor plaatsing binnen Kwaliteit van leven. Het ervan (kunnen) genieten stond centraal, blijkens de samenhang die veel deelnemers tijdens het clusteren lieten zien.

'Ervaren gezondheid', een aspect van Kwaliteit van leven in het model van Huber, is niet genoemd door de deelnemers, maar is ook geen voor de hand liggend antwoord op de vraag 'Wat is gezondheid voor u?', de eerste vraag in de concept-mappingsessies.

- Binnen de dimensie Sociaal-maatschappelijk participeren is het aspect 'sociale en communicatieve vaardigheden' maar één keer genoemd, en wel in termen van 'goed Nederlands kunnen' door de groep Marokkaanse vrouwen. Omdat dit een heel praktische vaardigheid betreft, kan het ook als onderdeel van Dagelijks functioneren opgenomen worden. Een extra aspect van Sociaal- 
Tabel 3 Door mensen met een lage SES als kenmerken van gezondheid benoemde determinanten, gegroepeerd in drie clusters

\begin{tabular}{|c|c|c|c|}
\hline Extra cluster & Kenmerken gezondheid lage SES & Frequentie $^{\mathrm{a}}$ & Prioriteit $^{b}$ \\
\hline \multirow{9}{*}{$\begin{array}{l}\text { Leefstij// } \\
\text { manier van } \\
\text { leven }\end{array}$} & voldoende bewegen, sporten, actief zijn, auto laten staan & 9 & $1,7-4,7$ \\
\hline & niet roken, stoppen met roken & 4 & $2,2-3,1$ \\
\hline & geen alcohol drinken & 3 & $1,9-3,2$ \\
\hline & gezond eten (veel fruit en groente, regelmatig, aan tafel, gevarieerd eten, veel water drinken) & 9 & $1,6-4,5$ \\
\hline & voldoende slapen, goed slaapritme & 5 & $1,9-3,6$ \\
\hline & je lichaam goed verzorgen, hygiëne, zuinig op jezelf zijn, afvallen & 6 & $2,2-4,1$ \\
\hline & $\begin{array}{l}\text { ontspannen, voor jezelf opkomen, bewust leven, luisteren naar je gevoel, tijd voor jezelf nemen, gestructureerd } \\
\text { leven, meditatie }\end{array}$ & 7 & $1,3-3,6$ \\
\hline & leuke dingen doen, uitgaan, buiten zijn, hobby's uitoefenen, lekker eten & 8 & $0,8-4,3$ \\
\hline & $\begin{array}{l}\text { vriendelijk zijn, niet roddelen, openstaan voor anderen, andere mensen helpen, goed omgaan met de buren, } \\
\text { voor familie zorgen }\end{array}$ & 6 & $2,4-4,3$ \\
\hline \multirow{3}{*}{$\begin{array}{l}\text { Toegang tot } \\
\text { goede zorg en } \\
\text { ondersteuning }\end{array}$} & $\begin{array}{l}\text { goede zorg krijgen, goede medische hulp, mantelzorg, goede communicatie met je arts, goede medicatie, be- } \\
\text { zocht worden door verpleegkundige }\end{array}$ & 7 & $1,9-4,5$ \\
\hline & betaalbare zorg & 2 & $3,5-3,9$ \\
\hline & goede begeleiding van instanties, goede informatie, juiste ondersteuning om te doen wat je wilt & 3 & $2,0-3,8$ \\
\hline \multirow[t]{4}{*}{ Leefomgeving } & $\begin{array}{l}\text { gezond milieu, schone lucht, veel groen in de omgeving, zonnig weer, schoon drinkwater, veilige straten, toe- } \\
\text { gang tot gezonde voeding }\end{array}$ & 7 & $2,2-3,9$ \\
\hline & goed, licht en gezond huis hebben, gezonde werkplek & 6 & $2,1-4,2$ \\
\hline & saamhorigheid in de buurt, samen leven met elkaar, goede buren hebben, elkaar helpen, respect voor elkaar & 8 & $1,9-4,7$ \\
\hline & geen oorlog, vrijheid van meningsuiting, niet mishandeld worden & 2 & $2,8-3,9$ \\
\hline
\end{tabular}

maatschappelijk participeren dat in acht van de negen groepen is genoemd, is: 'goede band met gezin en familie'. Vooral bij de deelnemers met een migratieachtergrond en bij de voedselbankgebruikers in Vollenhove bleek het contact met gezin en familie heel belangrijk. Omdat dit aspect bovendien een heel specifieke invulling is van het hebben van betekenisvolle relaties in het algemeen, is ervoor gekozen het als een apart aspect op te nemen. Ook het hebben van huisdieren is in twee groepen genoemd. Omdat dit aspect maar weinig genoemd is, niet hoog geprioriteerd werd en bovendien tijdens het clusteren veelal gelinkt werd aan sociale contacten, is het niet als apart aspect maar als onderdeel van Sociale contacten opgenomen.

- Bij Dagelijks functioneren, ten slotte, zijn basale dagelijkse levensverrichtingen, zoals jezelf kunnen wassen of de trap op en af kunnen, niet door deelnemers expliciet genoemd. Wel is in twee groepen 'zelfstandig lichamelijk functioneren' genoemd. Ook instrumentele dagelijkse levensverrichtingen, zoals 'kleine dingen in het huishouden kunnen doen' of 'overal naar toe kunnen', zijn in twee groepen genoemd. Vooral in de eerste Amsterdamse bijeenkomst, waar de gemiddelde leeftijd hoger was dan in de andere groepen, vond men deze aspecten belangrijk. Verschillende varianten van gezondheidsvaardigheden zijn wel in vijf groepen genoemd, zoals 'op tijd naar de dokter gaan', 'bewust met je gezondheid omgaan' en 'naar mijn lichaam luisteren'.
Hoewel het de vraag is of mensen met een lage SES de aspecten op vergelijkbare wijze zullen conceptualiseren (getuige de onderling sterk verschillende clusters die deelnemers maakten), zijn de zes dimensies van Positieve Gezondheid in de resultaten van de conceptmappingsessies terug te vinden. In fig. 2 is, op basis van deze resultaten, een aangepast spinnenweb voor mensen met een lage SES geschetst, waarbij aan de oorspronkelijke namen van de dimensies is vastgehouden.

Een interessante waarneming is dat de dimensies Lichaamsfuncties en Mentaal welbevinden in het resulterende spinnenweb van fig. 2 een vergelijkbare structuur hebben. Beide hebben een medische component: 'medische feiten en waarnemingen' versus 'psychische stoornissen en verslavingen'. Beide hebben ook een component die verwijst naar het functioneren: respectievelijk 'lichamelijk functioneren' en 'cognitief functioneren', en een ervaringscomponent: 'leven zonder klachten en pijn' en 'geestelijk goed voelen'. Het aspect 'geen zorgen of stress hebben' komt dicht bij de laatste in de buurt. Ten slotte hebben beide een component die verwijst naar veerkracht. Waar mentale veerkracht bij Huber onderdeel is van de dimensie Mentaal welbevinden, hebben de lage SES-deelnemers 'goede weerstand' als aspect van gezondheid naar voren gebracht, de lichamelijke variant van veerkracht. Veerkracht zelf is niet als zodanig genoemd tijdens de bijeenkomsten, maar is beschreven als 'leren leven met pijn', 'niet bij de pakken neerzitten', 'omgaan met je rugzakje' en 'innerlijke kracht'. 
Figuur 3 Ringen van determinanten om het spinnenweb van indicatoren van Positieve Gezondheid

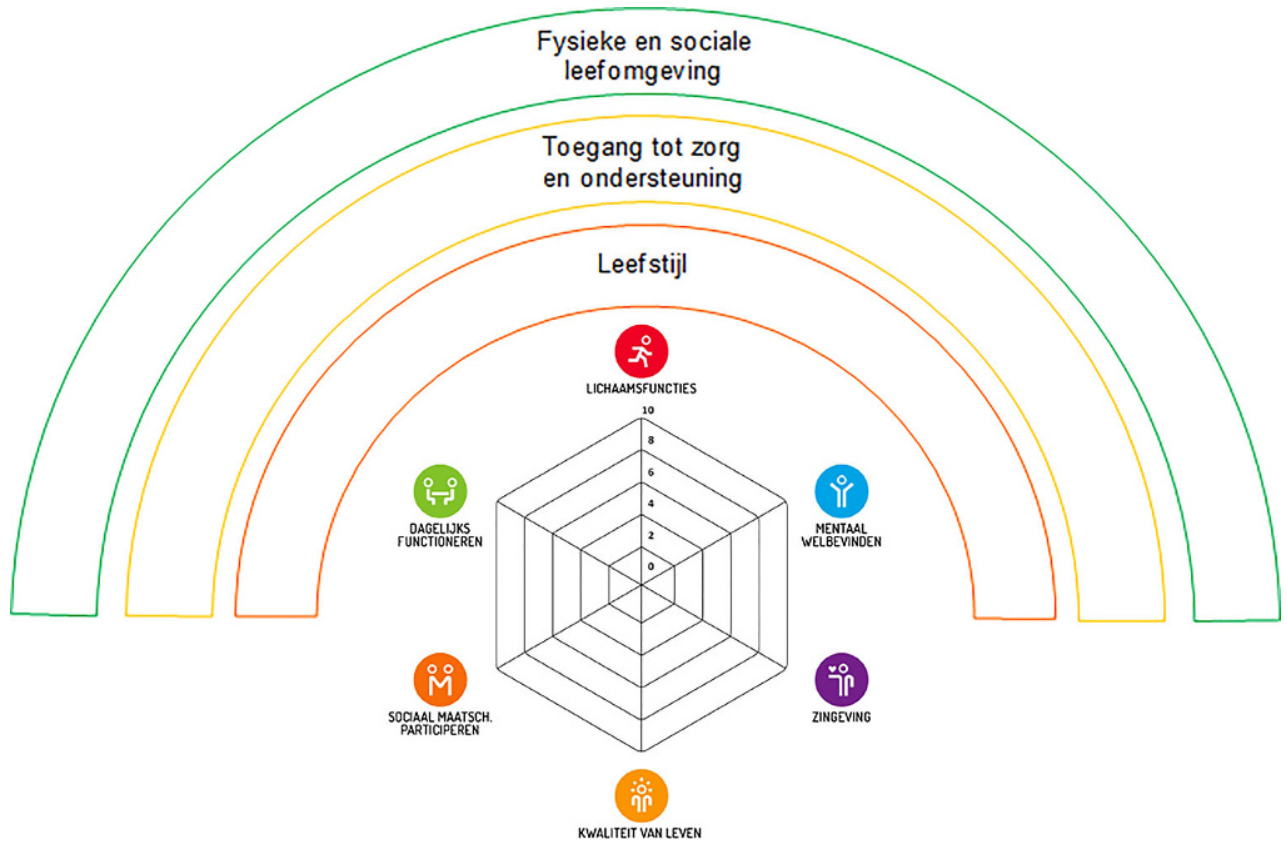

Een ander aspect dat daar dicht bij in de buurt komt, is 'positief zijn'.

\section{Determinanten van gezondheid}

Behalve bovenstaande aspecten, die we, net als in het model van Huber, als indicatoren van gezondheid beschouwen, zijn in de concept-mappinggroepen ook veel aspecten genoemd die meer naar determinanten van gezondheid verwijzen [20-22], oorzaken of bronnen van gezondheid en aangrijpingspunten voor gezondheidsbevorderende maatregelen. Deze zijn minder goed in de zes dimensies van Positieve Gezondheid in te delen en daarom ondergebracht in drie extra dimensies of clusters (tab. 3):

1. aspecten gerelateerd aan de persoonlijke leefstijl of manier van leven, zoals 'veel wandelen', 'gezond eten' en 'je lichaam goed verzorgen';

2. aspecten gerelateerd aan de fysieke en sociale omgeving, zoals 'schone buitenlucht', 'veel groen in de leefomgeving' en 'saamhorigheid in de buurt';

3. aspecten gerelateerd aan de toegankelijkheid van zorg en ondersteuning, zoals 'goede informatie krijgen van je arts', 'betaalbare zorg' en 'hulp krijgen in het openbaar vervoer'.

Deze determinanten horen niet in een indicatorenmodel zoals het spinnenweb van Positieve Gezondheid. Omdat het voor deelnemers zelf belangrijke aspecten zijn, kan overwogen worden om deze determinanten toch een plek in het geheel te geven. Ze zouden bijvoorbeeld, zoals weergegeven in fig. 3 , als schillen om het spinnenweb heen getekend kunnen worden, naar analogie met het determinantenmodel van Dahlgren en Whitehead [7].

\section{Conclusie}

Uit de resultaten van de concept-mapping blijkt dat gezondheid voor mensen met een lage SES dezelfde breedte heeft als het concept Positieve Gezondheid. In hun perceptie komen alle zes dimensies van het spinnenwebmodel terug. Wel verschillen zij in de aspecten die eronder vallen. Om beter aan te sluiten bij de belevingswereld van deze groep stellen wij op basis van onze resultaten enkele aanpassingen voor in het model (fig. 2).

Daarnaast kan het spinnenweb uitgebreid worden met drie clusters determinanten van (positieve) gezondheid, zoals in fig. 3 is geschetst. Gezond eten, veel beweging en voldoende groen in de buurt zijn voor mensen met een lage SES net zo goed aspecten van gezondheid als een gezond lichaam hebben of gelukkig zijn. Hiermee is de aansluiting bij de gezondheidsperceptie van mensen met een lage SES nog groter. Bovendien biedt het professionals aanknopingspunten om oorzaken en oplossingsrichtingen in kaart of ter sprake te brengen.

\section{Validiteit en betrouwbaarheid}

In dit onderzoek staat de gezondheidsperceptie van mensen met een lage SES centraal. In hoeverre hebben we daadwerkelijk mensen met een lage SES gesproken? De sociaaleconomische status van mensen wordt bepaald door meerdere factoren, zoals opleidingsniveau, inkomensniveau en positie op de arbeidsmarkt, wat het selecteren op lage SES moeilijk maakt. In Utrecht, Amsterdam en Rotterdam is gekozen voor selectie op laag opleidingsniveau, een keuze die om methodologische en praktische redenen vaak wordt gemaakt. In Rotterdam is bovendien naar de 
positie op de arbeidsmarkt gekeken (werkzoekenden). In Vollenhove is geselecteerd op een laag inkomensniveau (voedselbank) en in Eindhoven is een groep allochtone vrouwen benaderd, een doelgroep die vaak een lage SES heeft.

Doordat er niet geselecteerd is op alle aspecten van lage SES, hebben er ook mensen deelgenomen die naar verwachting strikt genomen geen lage SES hadden. Zo was er in Amsterdam een deelneemster die weliswaar laagopgeleid is, maar zichzelf zodanig goed ontwikkeld heeft dat zij zeker geen lage SES heeft. In Vollenhove kampte een deelnemer met armoede en maakte gebruik van de voedselbank terwijl hij wel hoogopgeleid is. Afgaande op onze ervaringen in de groepen schatten wij dat circa $90 \%$ van alle deelnemers een lage SES had en dat de $10 \%$ niet-lage SES het resultaat nauwelijks beïnvloed heeft.

Tijdens de analyse bleek dat het onderbrengen van de door de respondenten genoemde gezondheidsaspecten in het model van Huber minder vanzelfsprekend is dan verwacht. Veel aspecten zijn binnen meerdere dimensies te plaatsen, wat bij de onderzoekers geregeld tot discussie leidde. Zo is de uitspraak 'dat het met de kinderen goed gaat' te interpreteren als 'geen zorgen of stress hebben' binnen mentaal welbevinden, als 'betekenisvolle relaties' binnen Sociaalmaatschappelijk participeren, maar ook als 'doelen en idealen nastreven' binnen de dimensie Zingeving. Deze uiteenlopende interpretatiemogelijkheden maken het lastig om tot eenduidige, betrouwbare resultaten te komen. Het betrekken van de respondenten bij de analyse zou hiervoor geen oplossing bieden. Uit de clusteringresultaten van de concept-mappingsessies is gebleken dat ook de deelnemers onderling het lang niet altijd eens zijn over de betekenis en indeling van aspecten.

Tegelijkertijd is het de vraag hoe relevant dergelijke discussies zijn. Hoewel het model van Positieve Gezondheid vooral vanwege de breedte en het cliëntperspectief een heel bruikbaar model is, blijft het, zoals alle indelingen en modellen, een reductie van de werkelijkheid.

\section{Het spinnenweb nader beschouwd}

Om het spinnenwebmodel van Positieve Gezondheid goed in de praktijk te kunnen toepassen, is het essentieel dat de inhoud en het taalgebruik aansluiten bij de wereld van de gebruikers. Voor GGD'en zijn dat vaak mensen met een lage SES. Veel termen in het oorspronkelijke spinnenweb zijn voor deze mensen te abstract en te theoretisch. Daarom heeft het Institute of Positive Health in 2016 een aangepast spinnenweb als gespreksinstrument in begrijpelijke taal gelanceerd: Mijn Positieve Gezondheid [23]. Hiervoor zijn echter geen mensen met een lage SES geraadpleegd, maar is een taalbureau ingeschakeld. Het daadwerkelijk betrekken van mensen met een lage SES heeft aanvullende inzichten opgeleverd. De lage SES-va- riant, zoals weergegeven in fig. 2, kan als inspiratie dienen om het bestaande gespreksinstrument verder toe te snijden op een breder publiek of althans aan te laten sluiten bij mensen met een lage SES.

Het meenemen van drie typen determinanten, gezonde leefstijl, gezonde leefomgeving en toegang tot hulp en ondersteuning, doet extra recht aan het perspectief van mensen met een lage SES. In het gespreksinstrument Mijn Positieve Gezondheid is daar al mee gestart door bijvoorbeeld 'hoe je woont' en 'rondkomen met je geld' op te nemen in de dimensie Kwaliteit van leven. Daarmee is het onderscheid tussen indicatoren en determinanten losgelaten. Weliswaar is dat voor een gespreksinstrument niet erg, maar voor een beleidsinstrument is het niet handig. Het plaatsen van determinanten in ringen rondom het spinnenweb is wellicht een alternatief.

Het concept Positieve Gezondheid met de zes dimensies staat nog geregeld ter discussie. Vooral vanuit wetenschappelijk-theoretische hoek zijn er kritische noten [24]. Het spinnenweb van Positieve Gezondheid is echter geen theoretisch construct, maar een construct dat is gebaseerd op stakeholderonderzoek. Uit het onderzoek van Huber blijkt dat verschillende stakeholders anders aankijken tegen gezondheid; voor de constructie van het uiteindelijke model met de zes dimensies ging Huber uit van het brede perspectief van patiënten $[2,25]$.

In de praktijk blijkt het spinnenweb goed te werken als gespreksinstrument binnen het contact tussen burger en professional [26]. Om de geschiktheid van het (aangepaste) spinnenweb als gespreksinstrument bij cliënten met een lage SES te onderzoeken, is het aan te raden ervaringen van hulpverleners met deze cliëntenpopulatie te evalueren.

Daarnaast is het model van positieve Gezondheid een inspirator binnen het veld van gezondheidszorg en -bevordering. De kracht zit in de essentie van het concept: 1) het besef dat gezondheid meer is dan de lichamelijke en geestelijke gezondheidstoestand en dat gezondheidsbevordering om een integrale aanpak vraagt, 2) het centraal stellen van het perspectief en de beleving van de burger/klant/patiënt, zowel in het beoordelen van de eigen gezondheid als in het aangeven van gewenste verbeterpunten en 3 ) de focus op het versterken van kwaliteiten in plaats van het oplossen van problemen.

Dit onderzoek heeft inzichten opgeleverd over de gezondheidspercepties van mensen met een lage SES. Voor het gebruik van het model van Positieve Gezondheid voor mensen met een lage SES is het aan te bevelen deze inzichten toe te voegen aan het oorspronkelijk model.

\section{Lage SES versus hoge SES}

Het is relevant om de gezondheidspercepties van mensen met een lage SES te vergelijken met die van mensen met een hoge SES. Wanneer we de relatie 
tussen SES en gezondheidsperceptie beter begrijpen, kan dat belangrijke inzichten opleveren voor het terugdringen van sociaaleconomische gezondheidsverschillen, een van de belangrijkste doelen van de publieke gezondheid. Daartoe zouden de uitkomsten van dit onderzoek vergeleken moeten worden met die van vergelijkbaar onderzoek onder mensen met een hoge SES. In Utrecht, Amsterdam en Rotterdam zijn concept-mappingbijeenkomsten gehouden met midden- en hogeropgeleiden. In een volgend artikel hopen wij hierop terug te komen.

Open Access This article is distributed under the terms of the Creative Commons Attribution 4.0 International License (http://creativecommons.org/licenses/by/4.0/), which permits unrestricted use, distribution, and reproduction in any medium, provided you give appropriate credit to the original author(s) and the source, provide a link to the Creative Commons license, and indicate if changes were made.

\section{Literatuur}

1. Huber M, Knottnerus AJ, etal. How should we definehealth? BMJ. 2011;343:d4163.

2. Huber M, Vliet $M$ van, Giezenberg $M$, et al. Towards a 'patient-centred' operationalisation of the new dynamic concept of health: a mixed methods study. BMJ Open. 2016;6(1):1-12.

3. Huber M, Vliet M van, Boers I. Heroverweeg uw opvatting van het begrip 'gezondheid. Ned Tijdschr Geneeskd. 2016;160:A7720.

4. Sociaal en Cultureel Planbureau. Sociaal en Cultureel Planbureau. Statusscores. Den Haag: Sociaal en Cultureel Planbureau. 2019. https://www.scp. nl/Onderzoek/Lopend_onderzoek/A_Z_alle_lopende_ onderzoeken/Statusscores. Geraadpleegd op: 1 dec 2017.

5. Rijksinstituut voor Volksgezondheid en Milieu. Een gezonder Nederland. Bilthoven: Rijksinstituut voor Volksgezondheid en Milieu. 2014. http:/ / www.eengezondernederland. nl/Heden_en_verleden. Geraadpleegd op: 2 jun 2017.

6. Mackenbach J, Stirbu I, Roskam A, et al. Socioeconomic inequalities in health in 22 European countries. N Engl J Med. 2008;359(12):1290. author reply 1290-1291.

7. Dahlgren G, Whitehead M. Policies and strategies to promote social equity in health. Background document to WHO-Strategy paper for Europe. Arbetsrapport 2007:14, Institute for Futures Studies. 2007. http://ideas.repec. org/p/hhs/ifswps/2007_014.html. Geraadpleegd op: 1 dec 2017.

8. Marmot M. Social determinants of health inequalities. Lancet. 2005;365(9464):1099-104.
9. Ministerie van Volksgezondheid, Welzijn en Sport. Landelijke nota gezondheidsbeleid 2016-2019. Kamerbrief. 2015.

10. FNO. Gezonde Toekomst Dichterbij. 2015. https://www. fnozorgvoorkansen.nl/gezonde-toekomst-dichterbij/. Geraadpleegd op: 1 jun 2017.

11. Nusselder WJ, Bruggink JW, Mackenbach J. Ongelijkheid in gezonde levensverwachting: een dubbel nadeel voor laagopgeleiden. Geron. 2017;3:14-8.

12. Heutink H, Diemen D van, Elzenga M, et al. Wat hebben mensen met lage en hogere SES zelf te zeggen over gezond leven. Tijdschr Gezondheidswet. 2010;1:10-2.

13. Ballering C, Schreurs H, Renders C, et al. Overgewicht IDN. Een inkijk in verhalen achter leefstijlgewoontes. Tijdschr Gezondheidswet. 2013;5:263-9.

14. Bukman AJ, Teuscher D, Feskens EJM, et al. Perceptions on healthy eating, physical activity and lifestyle advice: opportunities for adapting lifestyle interventions to individuals with low socioeconomic status. BMC Public Health. 2014;14(1):1036.

15. Broeder L den, Uiters E, Hofland A, et al. Local professionals' perceptions of health assets in a low-SES Dutch neighbourhood: a qualitative study. BMC Public Health. 2018;18(1):12.

16. Kooiker S. Sociaal-economische gezondheidsverschillen (SEGV) als wicked problem. Tijdschr Gezondheidswet. 2017;95:3-4.

17. Bon-Martens MJH van, Goor LAM van de, Holsappel JC, et al. Concept mapping as a promising method to bring practice into science. Public Health. 2014;128(6):504-14.

18. CBS.. Standaard onderwijsindeling 2016. Den Haag: CBS; 2016.

19. Burke JG, O'Campo P, Peak GL, et al. An introduction to concept mapping as a participatory public health research method. Glob Health Promot. 2007;2(10):68-73.

20. Golden SD, Earp JAL. Social ecological approaches to individuals and their contexts. Health Educ Behav. 2012;39(3):364-72.

21. Schulz A, Northridge ME. Social determinants of health: implications for environmental health promotion. Health Educ Behav. 2004;31(4):455-71.

22. Whitehead M, Dahlgren G. What can be done about inequalities in health? Lancet. 1991;338(8774):1059-63.

23. Institute for Positive Health. Mijn Positieve Gezondheid. Versie 1.0, oktober 2016. https://iph.nl/downloads/. Geraadpleegd op: 1 april 2019.

24. PoieszT, CarisJ,LapréF. Gezondheid: een definitie? Tijdschr Gezondheidswet. 2016;94(7):252-5.

25. Remmers L, Middelkoop B. Het concept van Positieve gezondheid. Epidemiol Bull. 2016;3:8-15.

26. Zorgvisie. Positieve gezondheid: 25 procent minder verwijzingen naar tweede lijn. https://www.zorgvisie. $\mathrm{nl} /$ positieve-gezondheid-minder-verwijzingen-naar-detweede-lijn/. Geraadpleegd op: $1 \mathrm{dec} 2017$. 